\title{
Psychoanalytic conceptual framework: a critical review of creativity in modeling inquiry training
}

\author{
Zaenal Sukawi ${ }^{1}$, Ahmad Khoiri ${ }^{\left.1^{*}\right)}$, Sri Haryanto ${ }^{1}$, Denok Sunarsi ${ }^{2}$ \\ ${ }^{1}$ Universitas Sains Al Quran Jawa Tengah di Wonosobo, Indonesia \\ ${ }^{2}$ Universitas Pamulang, Banten, Indonesia
}

\section{Article Info}

Article history:

Received Des $12^{\text {th }}, 2020$

Revised Jan $03^{\text {rd }}, 2021$

Accepted Feb 23 ${ }^{\text {rd }}, 2021$

\section{Keyword: \\ Creativity \\ Inquiry training \\ Psychoanalytic}

\begin{abstract}
The conceptual framework of psychoanalysis seeks to explain the nature and development of the personality of students through creative elements, namely motivation, emotions, and other internal creative aspects. Conceptual method of psychoanalytic approach as a determination of the implementation of the inquiry training model through a systematic review. Based on data analysis that: 1) student creativity can be explored through a psychoanalytic approach that expresses new ideas with students' intellectual freedom in the form of inquiry and problem-solving skills in their own way; 2) Creativity is based on Guilford's creative person who is built by conscious and unconscious efforts on neuroscience which gives rise to motivation, energy, ego to do creative ideas; 3) Different ways of creative students become important factors in determining discovery learning models. creativity is part of a personality that is encouraged to be creative if indeed they cannot meet sexual needs directly. Because their needs are not fulfilled, sublimation occurs, and finally, imagination emerges.
\end{abstract}

(C) 2021 The Authors. Published by Indonesian Institute for Counseling,

Education and Therapy (IICET). This is an open access article under the CC BY license (https://creativecommons.org/licenses/by/4.0/)

Corresponding Author:

Ahmad Khoiri,

Universitas Sains Al Quran Jawa Tengah di Wonosobo

Email: akhoiri@unsiq.ac.id

\section{Introduction}

The theory of creative personal formation is stated in the theory of psychoanalysis and Guilford. There are no people who are not creative, The subjectivity and objectivity of creativity are very diverse because of the unique dimensions, so that an appropriate learning model is needed to make it easier for students to maximize their creativity. creativity includes creative processes, attitudes and persons (Baron et al., 2015; Guilford, 1965, 1950; Torrance, 1976; TORRANCE, 1972; Wallach \& Torrance, 1968). The psychoanalytic theory seeks to explain the nature and development of human personality. The elements that are prioritized in this theory are motivation, emotions, and other internal aspects (Amabile, 1997; Simonton, 2010). Through studying a person's creativity, his / her personality development can be identified. An undeveloped person means that he is not a creative person, although a complete conclusion cannot be drawn, the relationship between personality and creativity has a close and inseparable relationship. A person's personality can change depending on what kind of thinking and perspective they are and how. Thinking activities that involve the brain to come up with creative ideas make it possible to have a good personality. The psychology that prioritizes research on awareness and views consciousness as the main aspect of mental life, psychoanalysis has an important role in conceptualizing it as a way of looking at the development of creative personality (A. Khoiri et al., 2019).

The low creativity is caused by 1) not being able to facilitate specific media and models to empower creativity maximally, only in the form of images from printed books held by each student (Tendrita et al., 2016), then learning activities use methods that are only limited to lecture and question and answer methods so that students become passive listening to explanations from the teacher and only answer when appointed 
by the teacher. Some teachers only consider creativity as a process that can only be done individually. Creativity is a skill that is needed in a classroom environment and can be developed through a group or individual learning approach. Creativity is an important part of skills in learning is a cognitive activity in finding solutions to solve a problem (Adams, 2005; Ahmad Khoiri \& Sunarno, 2019; Sunarsi, 2018; Udompong \& Wongwanich, 2014), and finding ideas. to solve these problems (Cornoldi et al., 2015) to help students develop their creativity in solving problems. Student creativity will grow well when students are aware of what they want to achieve, what activities they will do, and about the progress made by students through their creative ideas for science learning (Kembara et al., 2020). Habitual patterns whether consciously or unconsciously carried out by a person certainly have an impact on his mindset. Creative personal is accustomed to finding new ideas that are unique and different from one another. So that a person's personality is different from one another.

The relationship between psychoanalysis and education is very complex, in the sense that psychoanalysis has modified and enriched the level of behavior (attitudes) in terms of educational relations (the relationship between educators, parents, students concerned). The concept of psychoanalysis applied in education is education which leads to the creation of student creativity. Creativity is the part of the personality that is driven to be creative if indeed they cannot meet personal needs directly. Since their needs are not met, sublimation occurs and finally the imagination appears

\section{Method}

A systematic review (Davies et al., 2013; Ahmad Khoiri et al., 2020; Sunarsi, 2019). A source that builds the evidence for future research recommendations. the research process is presented (Figure 1). a set of explicit rules oriented towards completeness and transparency of implementation (Dixon-Woods, 2011) using qualitative data.

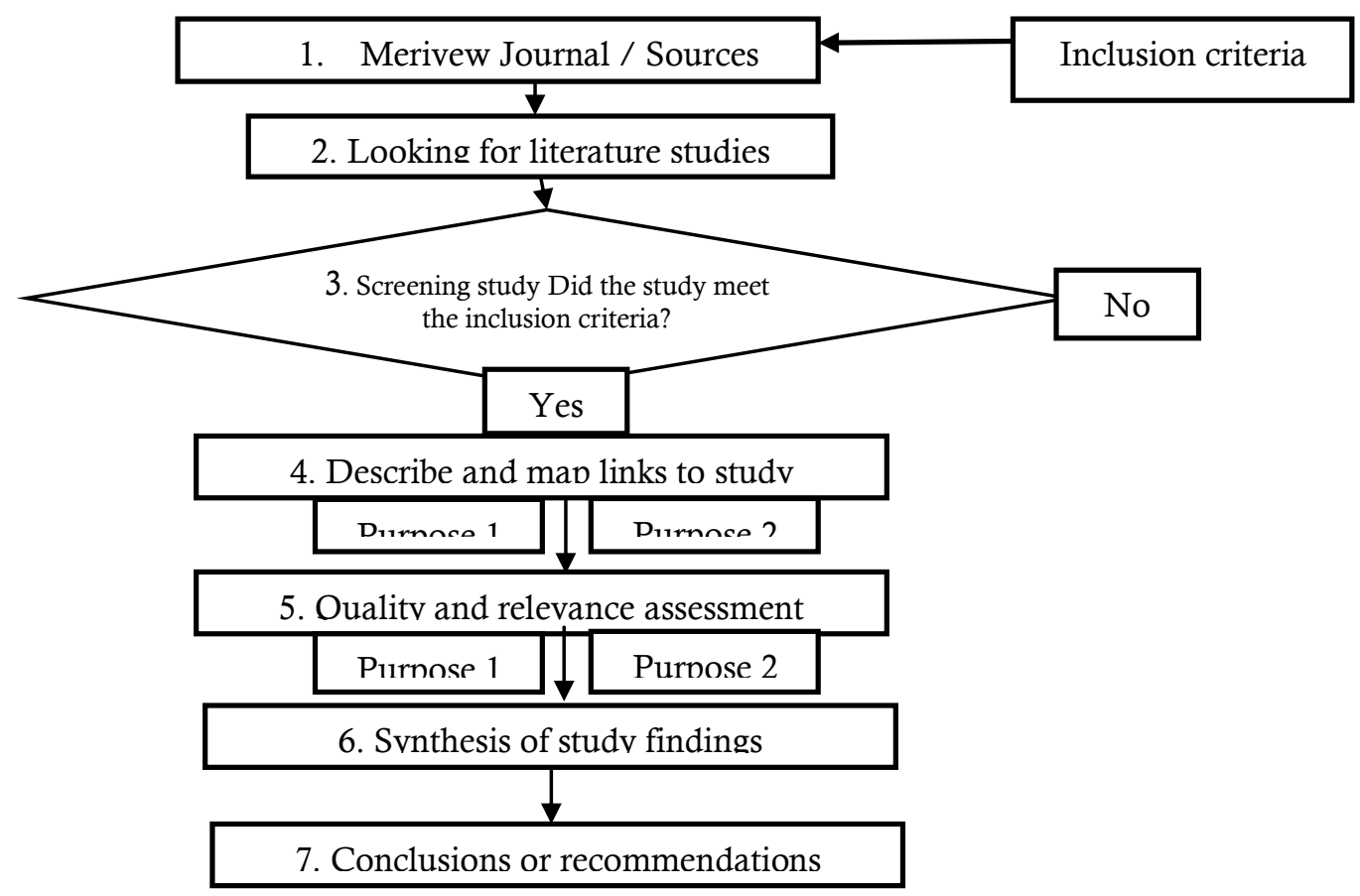

Figure 1. Sistematic Review Process (Davies et al., 2013)

Based on (Figure 1) the crucial question of inclusion as a research objective by identifying children's creativity through the use of the inquiry training model in psychoanalytic studies. 


\section{Results and Discussion}

The results of systematic review begin with inclusion criteria, synthesize the findings of literature studies, and provide conclusions or recommendations for further research. Presented in table 1 literature review in psychoanalysis studies.

Table 1. Literature Review Result Relationship of Inquiry Training, creativity and psychoanalysis

\begin{tabular}{|c|c|c|}
\hline Source & Description & Psychoanalysis \\
\hline $\begin{array}{l}\text { (Joyce et al., 2011) } \\
\text { (Adams, 2005; Piirto, } \\
\text { 2011) } \\
\text { (Frey, 2018; Şener et al., } \\
\text { 2015) } \\
\text { (Cremin et al., 2015) } \\
\text { (Hadzigeorgiou et al., } \\
\text { 2012) } \\
\text { (Ibrahim \& Irawan, } \\
\text { 2015; Sugiyanto et al., } \\
\text { 2018; Torrance, 1969) }\end{array}$ & $\begin{array}{l}\text { Contribution to increased creativity through inquiry } \\
\text { training } \\
\text { There is an increase in creativity by finding new } \\
\text { definitions by students. } \\
\text { scientific inquiry and creativity have a positive } \\
\text { relationship } \\
\text { Students intellectual abilities can be developed } \\
\text { through inquiry. } \\
\text { arouse the spirit of creativity with the inquiry process } \\
\text { in students } \\
\text { students' creative efforts through analysis and } \\
\text { evaluation thinking activities } \\
\text { seeing problems in a different light reinforces } \\
\text { indicators of creativity } \\
\text { open attitude to different perspectives in solving } \\
\text { problems } \\
\text { answers with new perspectives } \\
\text { Combining ideas into creative and original ideas } \\
\text { Effectiveness of ideas through a combination of ideas } \\
\text { and solutions }\end{array}$ & $\begin{array}{l}\text { The definition is new } \\
\text { because students } \\
\text { experience sublimation } \\
\text { and imagination } \\
\text { emerges } \\
\text { Real activity in the form } \\
\text { of inquiry can provide } \\
\text { stimulation to cognitive } \\
\text { development }\end{array}$ \\
\hline
\end{tabular}

The design of the causal relationship between psychoanalysis and creativity has the potential to determine the inquiry training model. Suchman's Inquiry Model Training (Suchman, 1964) exercises the inquiry process correctly and scientifically for the initial process of students in thinking (Adams, 2005). The goal is to develop a mindset with different perspectives so that ideas will emerge and be original and can provide alternative solutions to various problems. The Inquiry Training Model syntax is presented in Figure 2.

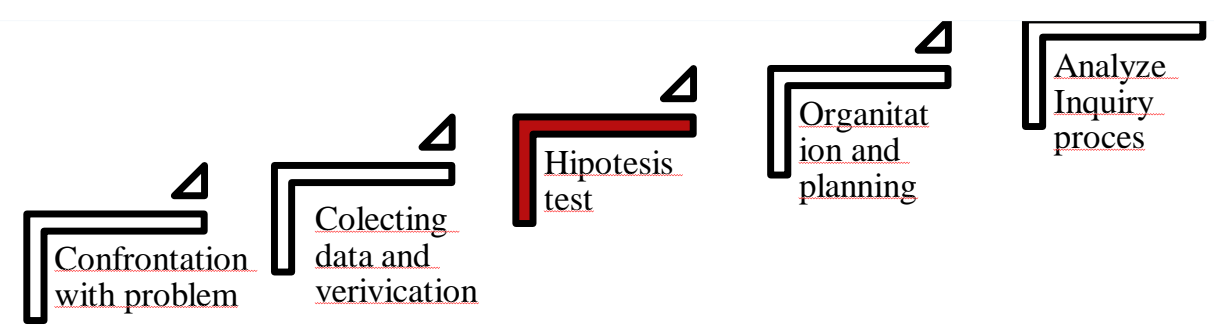

Figure 2. Inquiry Training Model Syntax (Joyce et al., 2011)

\section{Inquiry Training Model Syntax}

(Joyce et al., 2011) stated that the Inquiry Training Model Syntax: 1) Confrontation with a problem; 2) Data collection and verification (Collecting data and verification); 3) Data collection and hypothesis testing (Hypothesis test); 4) Organizing and formulating explanations (Organisation and planning), and 5) Analyze the inquiry process (Analyze Inquiry process). One learning model that has the potential to empower creativity is described through its learning syntax. 


\section{Confrontation with problems}

The inquiry model teaches students through the process of investigating and explaining unusual phenomena (A. Khoiri et al., 2019). The inquiry model teaches students through the process of investigating and explaining unusual phenomena. unusual things make students' curiosity increase, new knowledge enters and will experience a complex process of accommodation and assimilation with previous knowledge. (Piirto, 2011) unusual problems have the potential to create initial confusion among students, so that ideas will emerge naturally where the role of student curiosity increases. confusing means that there are initial concepts that have entered the realm of the brain and understanding. clarification of the problem and a combination of ideas are needed at this stage. students must move out of their comfort zone.

\section{Data collection and verification}

the process of gathering information to address the confusion of the unusual with new knowledge products. the verification process by choosing which ones are considered correct and incorrect (Ibrahim \& Irawan, 2015) selecting and filtering new knowledge to provide solutions to problems experienced by constructing ideas that have been previously obtained. the verification process will run into difficulties if the new knowledge and ideas gathered cannot accommodate the problem.

\section{Formulate a hypothesis}

The formulation of a hypothesis greatly determines learning outcomes in finding concepts. the formulated provisional assumption determines the knowledge in predicting a problem correctly. the accuracy of the proposed hypothesis depends on the individual student. the level of creativity and ideas contributed to the hypothesis.

\section{Organizing and Formulating Explanations}

data processing is done to develop ideas into meaningful concept representations. analysis, evaluation, description of data by explaining the meaning of the data makes students develop more imagination and creativity. open thinking and scientifically objectively will produce a complete concept (Akkaya \& Demirel, 2012; Coughlan, 2007; Ahmad Khoiri \& Sunarno, 2019)

\section{Analyze the process of inquiry (reflection or feedback)}

Finally, in the fifth stage, it evaluates research patterns carried out during the learning process. the process of creativity which is new and original ideas and ideas in expressing concepts in a different way for each individual. (Alameddine \& Ahwal, 2016; Malik et al., 2019) creativity that can be taken by getting out of the habit of yourself, out of the box experienced by each student will be different.

\section{The relation between Inquiry Training Model Components and Creativity Indicators}

The linkage can be assumed from the importance of creativity in science learning. The assumptions of linkage are explained through the relevant sources presented (Table 1) systematic review to provide an overview of research studies. Inquiry training model in empowering creativity. The findings produced in the form of an inquiry training model can directly increase and foster creativity without selecting certain indicators that are in creativity.

Table 1. Results of Systematic Review and Creativity Inquiry Training

\begin{tabular}{ll}
\hline Source & Findings \\
\hline (Anwar et al., 2012) & increased creativity through the process of inquiry training has great potential \\
(Cremin et al., 2015) & There is an increase in creativity by finding new definitions by students. \\
(Yang et al., 2016) & There is a relationship between creativity and scientific inquiry. \\
(A. Khoiri et al., 2019) & Development of creativity by building new concepts \\
(Ibrahim \& Irawan, & Intellectual students through knowledge, skiap and skills to build creative \\
2015) & $\begin{array}{l}\text { personnel } \\
\text { The spirit of creativity is shown through students' high curiosity when learning } \\
\text { concepts }\end{array}$ \\
(Simonton, 2012) & $\begin{array}{l}\text { Analysis of information and science concepts that go beyond high creative } \\
\text { attitudes }\end{array}$ \\
\hline
\end{tabular}

Based on (table 1), creative thinking activities through convergence in connecting ideas with one another. analyze patterns in inquiry exercises from different perspectives. collecting important ideas and ideas in examining the problem in a unique way, then the relationship between syntax and creativity indicators 
where there is a relationship between learning behavior and creative attitudes with each other based on the review results from the sources presented in (table 2).

Table 2. The Relationship between the Inquiry Training Model Syntax and the Creativity Indicators

\begin{tabular}{|c|c|c|c|c|c|c|}
\hline \multirow{2}{*}{$\begin{array}{l}\text { Inquiry } \\
\text { Syntax }\end{array}$} & \multirow[t]{2}{*}{ Activity } & \multicolumn{5}{|c|}{ Creativity Indicators (Guilford, 1968) } \\
\hline & & Fluency & Flexibility & Originality & Elaboration & Refidinition \\
\hline $\begin{array}{l}\text { 1. Confrontation with } \\
\text { problems }\end{array}$ & $\begin{array}{ll}\text { - Describe the } & \text { the } \\
\text { research procedure. } \\
\text { - explain the } \\
\text { differences. }\end{array}$ & $\sqrt{ }$ & $\sqrt{ }$ & - & - & - \\
\hline $\begin{array}{l}\text { 2. Data collection } \\
\text { and verification }\end{array}$ & $\begin{array}{l}\text { - Verify the nature of } \\
\text { the object and its } \\
\text { condition. } \\
\text { - Verify the events of } \\
\text { the problem state. }\end{array}$ & $\sqrt{ }$ & $\sqrt{ }$ & - & $\sqrt{ }$ & $\sqrt{ }$ \\
\hline $\begin{array}{l}\text { 3. Formulate a } \\
\text { hypothesis }\end{array}$ & $\begin{array}{l}\text { - Separating the } \\
\text { relevant variables. } \\
\text { - Hypothesizing (as } \\
\text { well as testing) the } \\
\text { causal }\end{array}$ & - & $\sqrt{ }$ & $\sqrt{ }$ & - & - \\
\hline $\begin{array}{l}\text { 4. Organizing and } \\
\text { Formulating } \\
\text { Explanations }\end{array}$ & $\begin{array}{l}\text { - Formulate rules and } \\
\text { explanations }\end{array}$ & $\sqrt{ }$ & $\sqrt{ }$ & - & $\sqrt{ }$ & \\
\hline $\begin{array}{lr}\text { 5. Analyze the } \\
\text { process of inquiry } \\
\text { (reflection } \\
\text { feedback) }\end{array}$ & $\begin{array}{l}\text { - Analyze research } \\
\text { patterns } \\
\text { - Developing the } \\
\text { most effective } \\
\text { activities }\end{array}$ & - & - & - & $\sqrt{ }$ & $\sqrt{ }$ \\
\hline
\end{tabular}

Based on (table 2) convergent thinking in making decisions as a sign of a creative person. thinking with multiple solutions and perspectives and not imitating others is much better (Collete \& Chiappetta, 1994). the inquiry training model is very different from conventional in developing creative ideas. The following is presented in table 3 in developing the indicators of creativity found from the results of relevant research. .

Table 3. Research results on each indicator of creativity in psychoanalysis

\begin{tabular}{|c|c|c|c|}
\hline $\begin{array}{l}\text { Creativity } \\
\text { Indicators }\end{array}$ & Indicators Sub & Source & \\
\hline Fluency & $\begin{array}{lll}- & \text { the ability } & \text { to } \\
& \text { generate ideas }\end{array}$ & $\begin{array}{l}\text { (Adams, 2005; } \\
\text { Piirto, 2011) }\end{array}$ & $\begin{array}{ll}\text { - } & \text { creative efforts with analyzing } \\
\text { activities }\end{array}$ \\
\hline Flexibility & $\begin{array}{l}\text { - look at the problem } \\
\text { from different } \\
\text { perspectives }\end{array}$ & (Swarz, 1988) & $\begin{array}{l}\text { different perspectives on } \\
\text { responding to problems is a } \\
\text { unique way }\end{array}$ \\
\hline & & $\begin{array}{l}\text { (Ibrahim \& } \\
\text { Irawan, 2015) }\end{array}$ & $\begin{array}{l}\text { - open attitude to students who } \\
\text { are able to solve problems }\end{array}$ \\
\hline Originality & $\begin{array}{l}\text { - the resulting idea is } \\
\text { new and unique to } \\
\text { each individual }\end{array}$ & $\begin{array}{l}\text { (Hadzigeorgiou } \\
\text { et al., 2012) } \\
\text { (Anwar et al., } \\
\text { 2012) }\end{array}$ & $\begin{array}{l}\text { - students' new discoveries in } \\
\text { overcoming problems } \\
\text { - incorporation of ideas into } \\
\text { something original }\end{array}$ \\
\hline Elaboration & $\begin{array}{l}\text { - } \quad \text { analyze and deepen } \\
\text { his ability to come } \\
\text { up with ideas }\end{array}$ & (Diki, 2014) & $\begin{array}{l}\text { memesan masalah melalui } \\
\text { rumusan rumusan ide kreatif }\end{array}$ \\
\hline Redefinition & $\begin{array}{l}\text { redefined in order } \\
\text { to evaluate the } \\
\text { concepts that have } \\
\text { been obtained }\end{array}$ & $\begin{array}{l}\text { (Daniel Tan \& } \\
\text { Kim, 2012) }\end{array}$ & $\begin{array}{l}\text { synthesis in making idea } \\
\text { analysis more effective }\end{array}$ \\
\hline
\end{tabular}


Based on (table 3) the attitude of creativity is characterized by complex thinking activities. Illustration of the process of empowering creativity by learning inquiry exercises in Figure 3.

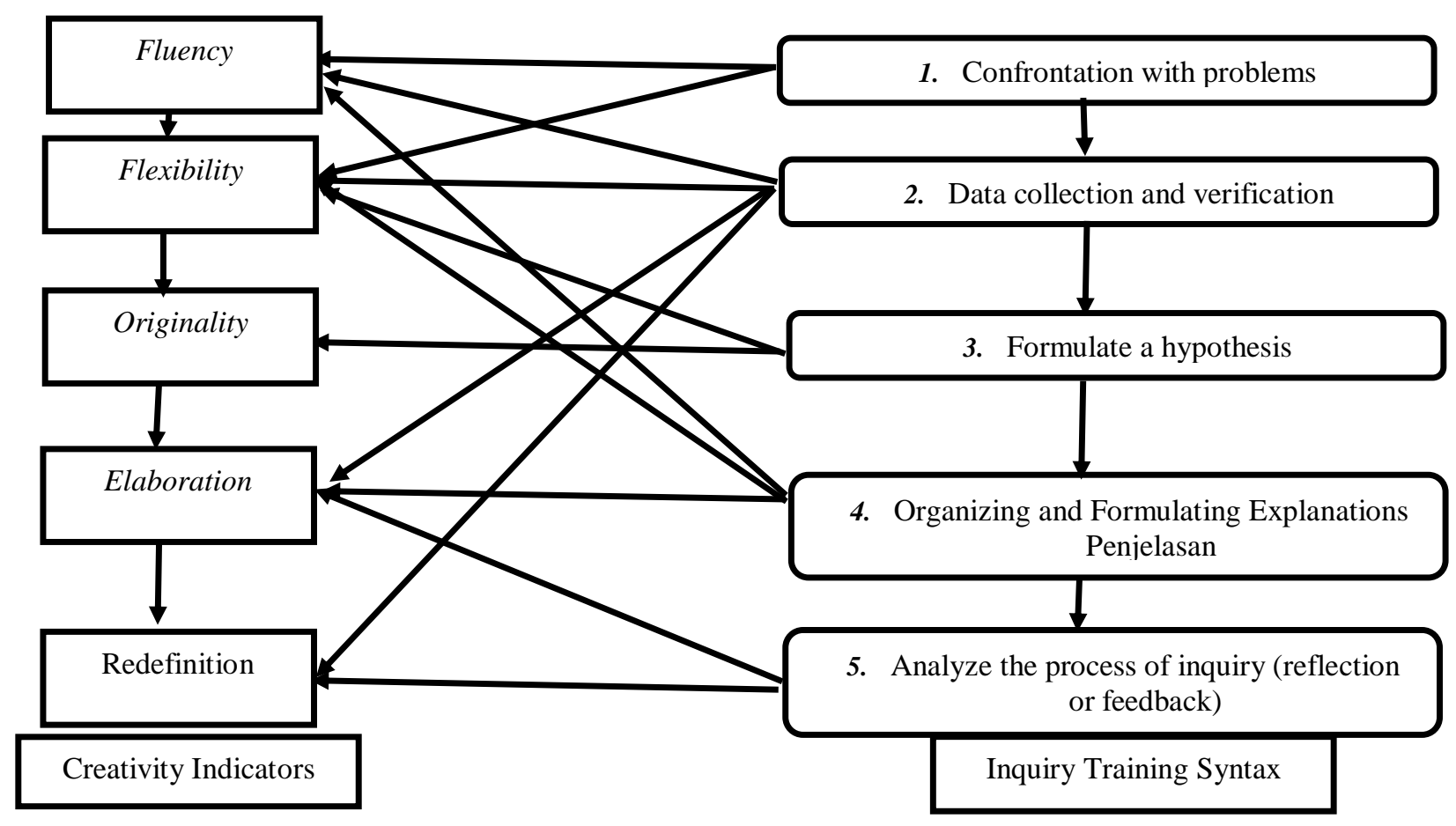

Figure 3. The syntactic causal process of the Inquiry Training Model and creativity indicators

The relationship between the components of the inquiry training model (Figure 3) shows the activities carried out by students in extracting information from different points of view, convergent thinking, training the scientific process in an open way. analytical thinking by combining ideas into new concepts and knowledge. students will not be able to carry out the creative process if they are still in their comfort zone. because of the requirements of creativity in a psychoanalytic review that it must come out of the individual's ego that it must change and produce something new. out of the box is highly recommended to get out of your comfort zone. Psychoanalysis contributes various thoughts in the development of the world of education. Psychoanalysis has a lot to say about personality, especially in terms of its structure, dynamics, and development. Through the application of the discovery model, namely inquiry training as a therapy or treatment to students in empowering the creative spirit of students. Creative Process (Roswendi et al., 2020; Wallach \& Torrance, 1968) the process of creativity through four stages, namely: Preparation, namely the preparation stage, the individual mind explores problems, Incubation, which is internalized to the subconscious, Illumination or insight, namely the stage of creative ideas coming out of the subconscious to become conscious, Verification, namely ideas are consciously verified, elaborated, and implemented. A combination of ideas from something unique will produce new ideas that are different from one another (Anwar et al., 2012);(4) the ability to elaborate by detailing ideas in detail will add effectiveness in the students' creative thinking process. the perspective of each element of the elements synthesizes and evaluates the concept in a variety of ways with different points of view(Ahmad Khoiri, 2019; Ahmad Khoiri \& Sunarno, 2019; Malik et al., 2019); (5) Redefinition by re-developing the results of ideas to evaluate the accuracy and accuracy in exploring a problem through an inquiry (Mer, 2007; Peters, 2017; Wenning, 2009).

\section{Conclusion}

The guilford creative person or person is built by conscious and unconscious efforts in neuroscience that generate motivation, energy, ego to carry out creative ideas. Unmet personal needs give rise to creativity when there is sublimation which is the beginning of imagination. The potential of inquiry training facilitates creative students through cognitive development that is trained continuously in the training or guidance process. Creative person is characterized by intellectual freedom in the form of inquiry and problem solving skills in their own way through inquiry training. 


\section{References}

Adams, K. (2005). The Sources of Innovation and Creativity. In National Center on Education and the Economy (NCEE) Research Summary and Final Report. https://files.eric.ed.gov/fulltext/ED522111.pdf

Akkaya, N., \& Demirel, M. V. (2012). Teacher Candidates' Use of Questioning Skills in During-Reading and Post-Reading Strategies. Procedia - Social and Behavioral Sciences, 46, 4301-4305. https://doi.org/10.1016/j.sbspro.2012.06.244

Alameddine, M. M., \& Ahwal, H. W. (2016). Inquiry Based Teaching in Literature Classrooms. Procedia Social and Behavioral Sciences, 232(April), 332-337. https://doi.org/10.1016/j.sbspro.2016.10.031

Amabile. (1997). Motivating Creativity in Organizations: On Doing What You Love and Loving what you do. California Management Review, 40(I), 39-59.

Anwar, M. N., Aness, M., Khizar, A., Naseer, M., \& Muhammad, G. (2012). Relationship of Creative Thinking with the Academic Achievements of Secondary School Students. International Interdisciplinary Journal of Education, 1(3), 1-4. http://iijoe.org/IIJE_01_03_12.pdf

Baron, J., Scott, S., Fincher, K., \& Emlen Metz, S. (2015). Why does the Cognitive Reflection Test (sometimes) predict utilitarian moral judgment (and other things)? Journal of Applied Research in Memory and Cognition, 4(3), 265-284. https://doi.org/10.1016/j.jarmac.2014.09.003

Collete \& Chiappetta. (1994). Science Instruction in the middle and secondary school (3rd.ed). In New York: Merril.

Cornoldi, C., Carretti, B., Drusi, S., \& Tencati, C. (2015). Improving problem solving in primary school students: The effect of a training programme focusing on metacognition and working memory. British Journal of Educational Psychology, 85(3), 424-439. https://doi.org/10.1111/bjep.12083

Coughlan, A. (2007). Creative thinking and critical Thinking. In Www.Dcu.Ie/Sites/Default/Files/Students/Studentlearning/Creativeandcritical.Pdf(Issue 1989).

Cremin, T., Glauert, E., Craft, A., Compton, A., \& Stylianidou, F. (2015). Creative Little Scientists: exploring pedagogical synergies between inquiry-based and creative approaches in Early Years science. Education 3-13, 43(4), 404-419. https://doi.org/10.1080/03004279.2015.1020655

Daniel Tan, K. C., \& Kim, M. (2012). Issues and challenges in science education research: Moving forward. Issues and Challenges in Science Education Research: Moving Forward, April, 1-350. https://doi.org/10.1007/978-94-007-3980-2

Davies, D., Jindal-Snape, D., Collier, C., Digby, R., Hay, P., \& Howe, A. (2013). Creative learning environments in education-A systematic literature review. Thinking Skills and Creativity, 8(1), 80-91. https://doi.org/10.1016/j.tsc.2012.07.004

Diki, D. (2014). Creativity for Learning Biology in Higher Education. Lux, 3(1), 1-12. https://doi.org/10.5642/lux.201303.03

Dixon-Woods, M. (2011). Systematic reviews and qualitative methods. In D. Silverman (Ed.). Qualitative Research. London: Sage.

Frey, B. B. (2018). Torrance Tests of Creative Thinking. In The SAGE Encyclopedia of Educational Research, Measurement, and Evaluation. https://doi.org/10.4135/9781506326139.n705

Guilford. (1965). Intelligence: 1965 Model. University of Southern California E, 20-26.

Guilford, J. P. (1950). Creativity. American Psychologist, 5, 444-454.

Guilford, J. P. (1968). Intelligence, Creativity, and Their Educational Implications. California: RR. Knapp.

Hadzigeorgiou, Y., Fokialis, P., \& Kabouropoulou, M. (2012). Thinking about Creativity in Science Education. Creative Education, 03(05), 603-611. https://doi.org/10.4236/ce.2012.35089

Ibrahim, M., \& Irawan, A. (2015). Effectivity of Peer Tutoring Learning to Increase Mathematical. International Journal of Education and Research, 3(1), $613-628$. https://doi.org/10.1038/NPHOTON.2012.146

Joyce, B., Weil, M., \& Calhoun, E. (2011). Models of teaching. Pustaka Pelajar.

Kembara, M. D., Hanny, R., Gantina, N., \& Kusumawati, I. (2020). Scientific Literacy Profile Of Student Teachers On Science For All Context. November.

Khoiri, A., Sunarno, W., Sajidan, \& Sukarmin. (2019). Inquiry training model to improve creativity student in environmental physics courses. AIP Conference Proceedings, 2194(December). https://doi.org/10.1063/1.5139781

Khoiri, Ahmad. (2019). Meta Analysis Study: Effect of STEM (Science Technology Engineering and Mathematic) towards Achievement. Formatif: Jurnal Ilmiah Pendidikan MIPA, 9(1), 71-82. https://doi.org/10.30998/formatif.v9i1.2937

Khoiri, Ahmad, \& Sunarno, W. (2019). How Is Students' Creative Thinking Skills ? An Ethnoscience Learning Implementation. Jurnal Ilmiah Pendidikan FisikaAl-BiRuNi, 08(October), $153-163$. 
https://doi.org/10.24042/jipfalbiruni.v0i0.4559

Khoiri, Ahmad, Sunarno, W., Sajidan, S., \& Sukarmin. (2020). Development of strategic environmental assessment (sea) in science learning. International Journal of Advanced Science and Technology, 29(7), 37713782.

Malik, A., Nuraeni, Y., Samsudin, A., \& Sutarno, S. (2019). Creative Thinking Skills of Students on Harmonic Vibration using Model Student Facilitator and Explaining (SFAE). Jurnal Ilmiah Pendidikan Fisika Al-Biruni, 8(1), 77-88. https://doi.org/10.24042/jipfalbiruni.v8i1.3056

Mer, A. C. İ. (2007). Effective Teaching in Science: A Review of Literature. Journal of Turkish Science Education, 4(1), 20-44.

Peters, V. U. (2017). Inquiry Based Science Education,: Scafolding Pupil Self Directed Learning in Open Inquiry. International Journal of Science Educational.

Piirto, J. (2011). Creativity for 21st. In Sense Publishers.

Roswendi, A. S., Khoiri, A., \& Sunarsi, D. (2020). Characters in hypno teaching and neuroscience: an overview. 8(3), 138-144.

Şener, N., Türk, C., \& Taș, E. (2015). Improving Science Attitude and Creative Thinking through Science Education Project: A Design, Implementation and Assessment. Journal of Education and Training Studies, 3(4), 57-67. https://doi.org/10.11114/jets.v3i4.771

Simonton, D. K. (2010). FEATURED ARTICLE : The Creative Process in Picasso 's Guernica Sketches : Monotonic Improvements versus Nonmonotonic Variants The Creative Process in Picasso 's Guernica Sketches: Monotonic Improvements versus Nonmonotonic Variants. Creativity Research Journal, September 2011, 37-41.

Simonton, D. K. (2012). Taking the U.S. Patent Office Criteria Seriously: A Quantitative Three-Criterion Creativity Definition and Its Implications. Creativity Research Journal, 24(2-3), 97-106. https://doi.org/10.1080/10400419.2012.676974

Suchman, J. R. (1964). The Illinois studies in inquiry training. Journal of Research in Science Teaching, 2(3), 230-232. https://doi.org/10.1002/tea.3660020315

Sugiyanto, F. N., Masykuri, M., \& Muzzazinah, M. (2018). Analysis of senior high school students' creative thinking skills profile in Klaten regency. Journal of Physics: Conference Series, 1006(1), 0-5. https://doi.org/10.1088/1742-6596/1006/1/012038

Sunarsi, D. (2018). Pengaruh Gaya Kepemimpinan dan Disiplin Kerja Terhadap Kinerja Karyawan Pada CV. Usaha Mandiri Jakarta. JENIUS (Jurnal Ilmiah Manajemen Sumber Daya Manusia), 1(2), 1-24. https://doi.org/10.32493/jjsdm.v1i2.919

Sunarsi, D. (2019). Pengaruh Kompensasi, Komunikasi Dan Stress Kerja Terhadap Prestasi Kerja Karyawan Pada Pt Catur Putra Jaya Kota Depok - Jawa Barat. Jimf (Jurnal Ilmiah Manajemen Forkamma), 1(2), 113-127. https://doi.org/10.32493/frkm.v1i2.2543

Swarz, J. D. (1988). The Torrance Tests of Creative Thinking. Test Critiques Vol. VII, 18(1), 619-662. https://www.tandfonline.com/doi/abs/10.1207/s15326934crj1801_3

Tendrita, M., Mahanal, S., \& Zubaidah, S. (2016). Empowerment of Creative Thinking Skills through Think Pair Share Remap Model. Proceeding Biology Education Conference (ISSN: 2528-5742), 13(1), 285-291.

Torrance. (1969). Creativity.'. What Research Says to the Teacher. National Education Association, Washington, ,D.C.- Association -of--Classroom Teachers.

Torrance, E. P. (1976). Future Careers for Gifted and Talented Students Gifted Child. Quarterly 20, 142-156.

Torrance, E. P. (1972). Predictive Validity of the Torrance Tests of Creative Thinking. The Journal of Creative Behavior, 6(4), 236-262. https://doi.org/10.1002/j.2162-6057.1972.tb00936.x

Udompong, L., \& Wongwanich, S. (2014). Diagnosis of the Scientific Literacy Characteristics of Primary Students. Procedia - Social and Behavioral Sciences, 116, 5091-5096. https://doi.org/10.1016/j.sbspro.2014.01.1079

Wallach, M., \& Torrance, E. P. (1968). Torrance Tests of Creative Thinking: Norms -- Technical Manual. American Educational Research Journal, 5(2), 272. https://doi.org/10.2307/1161826

Wenning, C. J. (2009). Scientific epistemology: How scientists know what they know. Journal of Physics Teacher Education Online, 5(2), 3-15. http://www.phy.ilstu.edu/jpteo/issues/aut2009.html

Yang, K. K., Lin, S. F., Hong, Z. R., \& Lin, H. S. (2016). Exploring the Assessment of and Relationship Between Elementary Students' Scientific Creativity and Science Inquiry. Creativity Research Journal, 28(1), 16-23. https://doi.org/10.1080/10400419.2016.1125270 